\title{
30. Wooden Shipbuilding on Lake Constance before 1900
}

\author{
Dietrich Hakelberg
}

The pre-Alpine lakes - such as Lake Geneva, Lake Zurich, Lake Constance and the smaller Lake Walenstadt - played an important role in transalpine transportation from Roman times onwards. Before the earliest railways, it was not only easier but far more economic to use waterways for transport of goods and people, particularly in view of the poor road conditions. Many roads crossing the pre-Alpine foreland and the trails coming down the river valleys from the Alpine passes were linked by these lakes, which were thus used for the distribution of transalpine and regional traffic (see Eitel, 1996). Ships were consequently a significant means of transportation on these inland waters. Lake Constance, bordering today on Switzerland, Austria and Germany, was always a focal point of political interests and was situated in the center of the bishopric of Konstanz. The firm grip on shipping by the early medieval monasteries St. Gallen and Reichenau (the latter just recently added to the UNESCO World Heritage list), the prospering trade of the medieval towns Konstanz and Lindau, late-medieval global trade and seafaring and finally post-medieval industrialization suggest that changing political and economic factors affected the organization of shipping on LakeConstance. Was there interaction between economical and technological changes and did they have an impact on shipbuilding? A study of the long-lived tradition of building wooden flat-bottomed sailing-vessels is highly dependent upon archaeology due to a paucity of other sources.

After having analyzed the well-known flat-bottomed Roman shipwrecks from Lake Neuchâtel, Béat Arnold was the first to point out the presence of comparable medieval and post-medieval shipwrecks in the lakes north of the Alps (Arnold, 1976; 1985; 1992: 102-107). Recent archaeological finds shed light on the keel-less bottombased construction and on the development of distinctive hull-designs on medieval and post-medieval Lake Constance.

In the 19th century, the Middle Ages were still omnipresent in the everyday life of the rural population. Learned people of the time were aware that the history of contemporary ships and shipping on Lake Constance was very old. The Swiss historiographer Georg Leonhard Hartmann wrote in 1808: "The ships of Lake Constance are very simply built and differ from one another only in size. ... It is quite remarkable that shipbuilding on this lake has not changed for centuries and that the various attempts at using ships of other designs have always failed" (Hartmann, 1808: 83).

Lädinen and Segner, both fitted with a trapezoidal square sail, were the two sizes of traditional flat-bottomed vessels on Lake Constance (Leidenfrost, 1975; Bloesch, 1988). They had differing load capacities, which both seem to have increased gradually starting in the 17th century (Leidenfrost, 1975: 23-35). The Lädinen, which reached a capacity of up to 150 tons toward the end of the 18th century, apparently vanished already in the first decade of the 19th century (Schwab, 1840: 23). The Segner was the smaller of the two types; it loaded ca. 44 tons and remained in use until about 1910 . Throughout the 19th century, this vessel took part in the hard everyday life of people, who still lived under social and technological circumstances that had not changed much since medieval times (Fig. 30.1). Even though the effects of the Enlightenment had made themselves be felt on the economic conditions on land, they did not have an impact on equally importanteconomic factors like the technical development of shipping on Lake Constance. As late as 1889 the newspaper Schwäbische Kronik (Swabian Chronicle), in an article entitled "The sailing ships on Lake Constance" (Die Segelschiffahrt auf dem Bodensee), remarked upon the "extremely poor knowledge of sailing, which results in the rigging and sail being absolutely insufficient". Sailing windward by tacking would be inconceivable, "until the construction of the sailing vessels, in particular the rigging and the cut of the sails has been improved. It would be a great economic gain if sailing on Lake Constance could thus be generally promoted". The shipwrights and shipmen, however, were very conservative, and thus retained the construction techniques that had been handed down by their forefathers. The shipmen were still organized in guilds and rejected the introduction, 


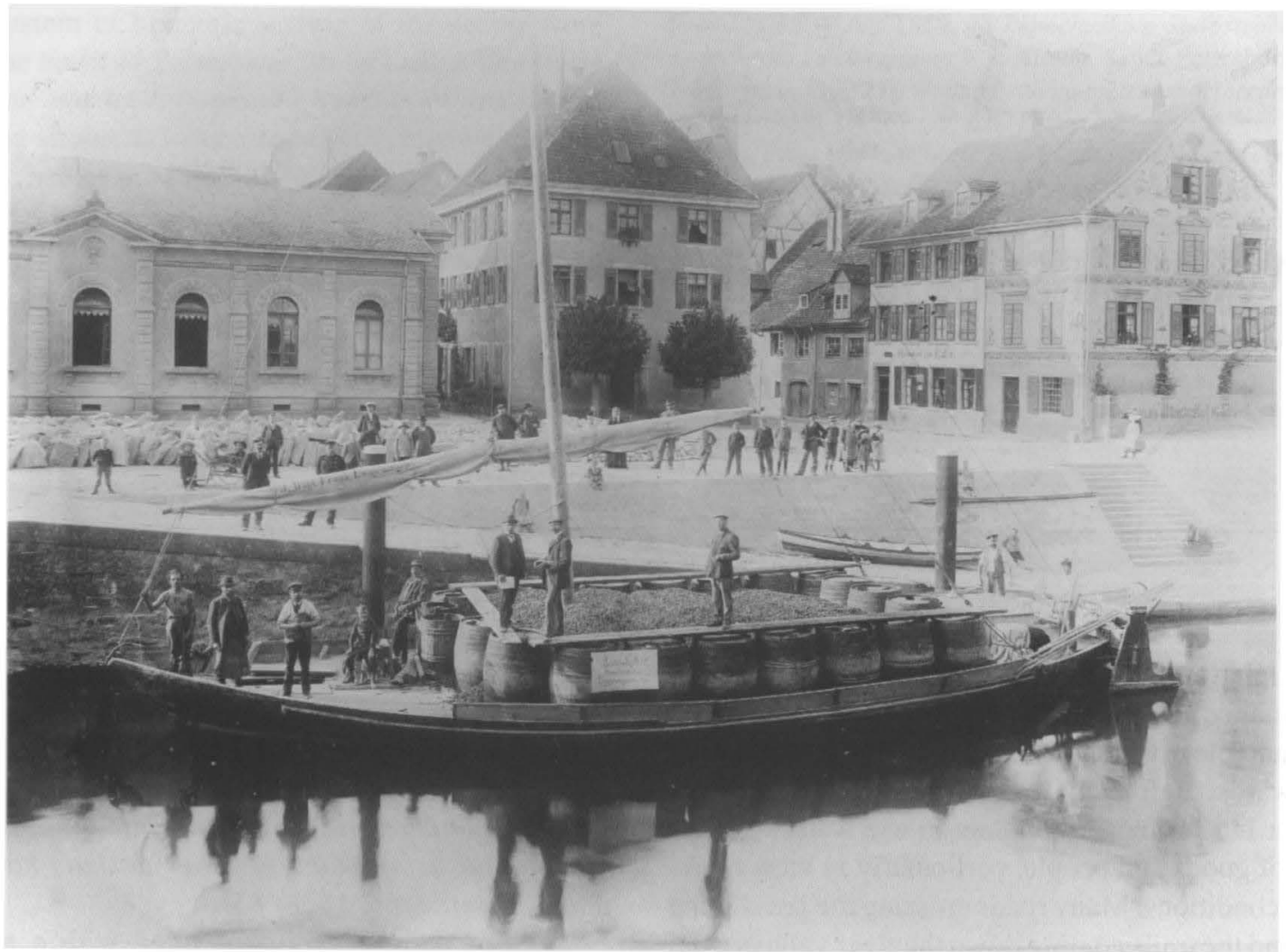

Fig. 30.I. A Segner in the harbour at Überlingen, Lake Constance, circa 1903 (courtesy of Siegfried Lauterwasser, Überlingen).

beginning 1824, of the steam engine to Lake Constance, which was however promoted by the progressive middle class (Siefken, 1978).

A "long Middle Ages" in the development of wooden shipbuilding on Lake Constance is reflected by various pictorial sources of the 15th to 19th centuries. Written sources do not supply any information about medieval shipbuilding, and archival records of the post Middle Ages provide only little information on ship dimensions. Master moulds or the like are not extant, and it is also very likely that drawings were never made. Some technical details can be ascertained from a few medieval and post-medieval paintings, others from early photographs. Exploring the technology and development of wooden shipbuilding on Lake Constance until the 19th century proves to be a real archaeological task.

Archaeological research on ships and shipping on Lake Constance was initiated by the discovery of a shipwreck in the shallow water zone at the Kippenhorn, a spit near the village of Immenstaad (Hakelberg, 1996). Archival sources and archaeological evidence of jetties testify to the presence of a landing place in the vicinity of the site, which was still in use in the 19th century. The shipwreck was dated by means of dendrochronology to the second quarter of the 14th century and gave first insights into medieval shipbuilding on Lake Constance. The wreck, still some $18 \mathrm{~m}$ in length, was what remained of a flatbottomed sailing vessel made of oak (Fig. 30.2).

The flat bottom - the fundamental feature of the bottom-based construction (see Rieth, 1981) - was built in three sections: the midship, built employing two chine strakes bearing an L-shaped rectangular profile and carved from two single oak logs, $11.60 \mathrm{~m}$ and $12.80 \mathrm{~m}$ long respectively; a sloping bow tapering forward, $7 \mathrm{~m}$ in length, and made up of broad planks of up to $70 \mathrm{~cm}$ in width; and the sloping non-tapering stern.

The bottom planks of both sloping bow and stern section were rabbetted and pinned to the horizontal midship bottom planking. The side planking overlapped the vertical side of the transition strake and was fastened with treenails, all wedged from in- and outboard. The side-planking extended beyond the edges of the sloping bottom fore and aft, where it was also fastened with treenails. The vertical side-planking apparently consisted of only one very broad strake, assembled of shorter planks which were hook scarfed to cope with the lengthwise tensile forces. Side-planking therefore guaranteed the sturdiness of the three portions of the ship's flat bottom (Fig. 30.4). Apparently due to a shortage of timber, there are many patches and filling pieces.

Bottom-based construction employing chine-strakes and vertical side planking resulted in a box-like hull form 


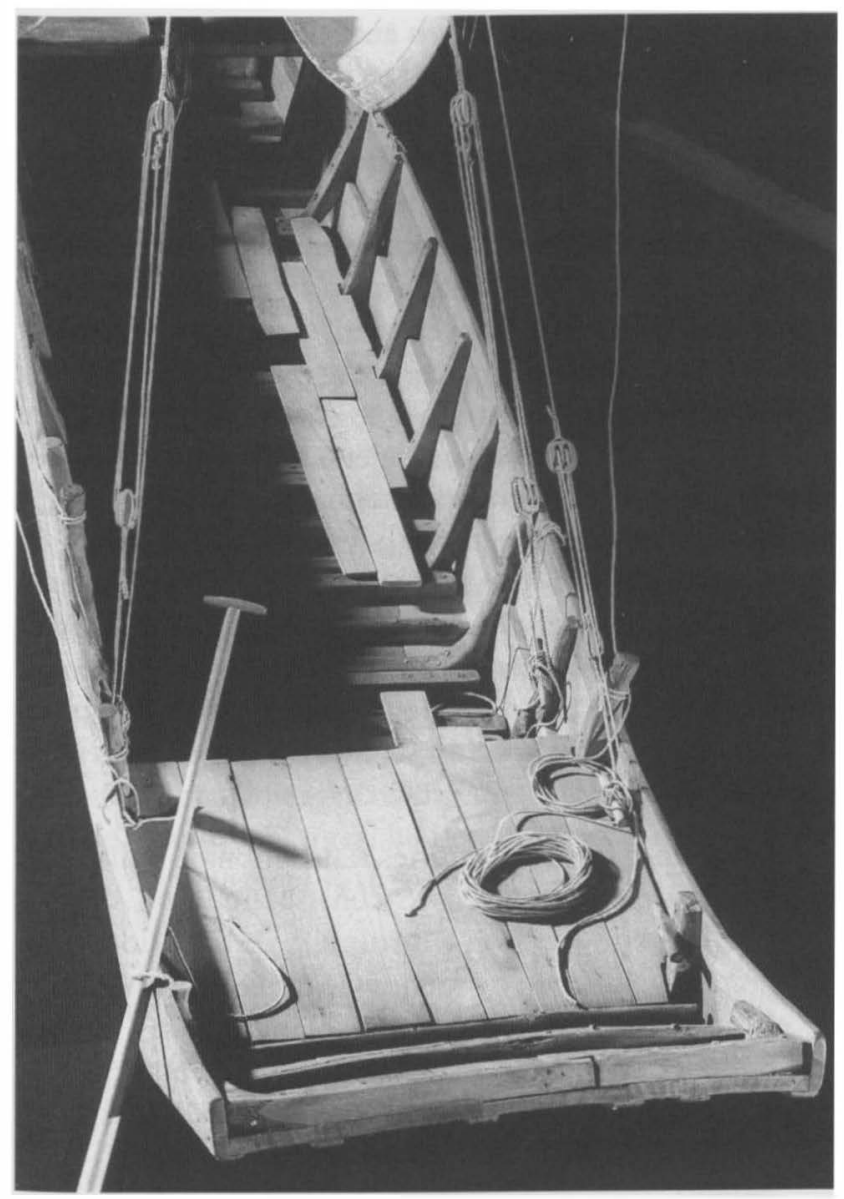

Fig. 30.2. The Immenstaad vessel (1325-1350) reconstructed in 1:10 scale (model: author; photo: M. Schreiner, Archäologisches Landesmuseum Konstanz).

with a slightly asymetrical polygonal ground plan. The highest preserved frame suggests a midship height of $c a$. $1.10 \mathrm{~m}$, whereas the bottom of the stern and bow rise to a height of $c a .2 \mathrm{~m}$. Frames were not installed until the plank shell had been completed. The frames were made of rectangular oak branches, hewn to shape and fixed by treenails. Paired frames alternate with single floor timbers. All joints were fastened with treenails, there are no iron nails.

Tow was used for caulking the hull. This coarse-fibred scrap from the linen production was mixed with tar or pitch. It was pressed into the seams, which were then covered by laths under the bow and stern. The laths were fixed by small iron nails to prevent the caulking from washing out. As far as I know, the use of tow in medieval shipbuilding is unique, as the hulls on central European inland waters were normally caulked with moss. Because the cultivation of hemp and flax flourished in the region around Lake Constance in the 14th and 15th centuries, the use of these fibres for ship caulking can be easily understood (von Stromer, 1986, 51-57). Hemp and flax were also raw materials for manufacturing ropes and sails, thus the vessel's indispensable textile fittings were produced in the immediate surroundings of Lake Constance. The rigging was quite simple - compared to seagoing vessels - and pictorial sources suggest that all the medieval vessels were equipped with a square sail, like the sailing vessels in the 19th century. The mast height of the Immenstaad vessel is estimated to have been $c a .10 \mathrm{~m}$.

Fragments of chine-strakes, dated by means of dendrochronology to the 12th century, were detected in the wooden linings of later medieval pits in the towns on Lake Constance and suggest the recycling of disposed scrap materials from dismantled vessels (Hakelberg, Tegel, 1996). If these archaeological finds are not entirely accidental, the monoxyle chine-strake could be considered a common structural component of medieval shipbuilding on Lake Constance. The prevailing evolutionary paradigm, that chine-strakes derive from a split-dugout concept, entails a chrono-technological premise which suggests that even medieval vessels built with chine-strakes are a somewhat archaic remnant of prehistoric or even "Celtic" shipbuilding. I believe, that things are not that simple. Instead of interpreting chine strakes from an evolutionary point of view a more technological and ergological track could be followed.

The chine, the sharp bend from the flat bottom to the more or less vertical side, is a constructional feature closely associated with the bottom-based construction. Chine-strakes strengthen the hull lengthwise and substitute, functionally speaking, for the keel. But whereas a keel represents a symmetrical axis for hull lines and frames, a flat bottom provides a plane. The outline of the plane forms the ground plan of the vessel. If the flat bottom is edged by chine strakes, i.e. the vessel has a monoxyle chine, the three-dimensional shape of these specialized wooden components determines the kind of side planking and the design of the flat-bottomed hull, too. Because of the hard chine, flat-bottomed hulls possess good hydrostatical stability and fit the environmental demands of the pre-Alpine lakes perfectly. Because of their shallow draught, they were advantageous in the broad shallow water zones near the shore line of Lake Constance, where the vessels could be punted alongside during calms. Flatbottomed vessels could also easily approach rural landing places that did not have any jetties. The hull shape made these ships a very suitable means of transport for the exchange between the countryside and the towns, which had harbours with more elaborate waterfront constructions.

Box-like and flat-bottomed hulls with sloping bows and sterns appear in pictorial sources of the 15th to 18th centuries. The earliest comes from an illuminated manuscript from the St. Gallen monastery near Lake Constance and dates from 1452 (Fig. 30.3). It shows a vessel with a box-like hull and sloping bow and stern, rowed by two men. The side planking seems to have been assembled of many planks. The sheer view corresponds perfectly to that of the 14th-century Immenstaad vessel. The long 


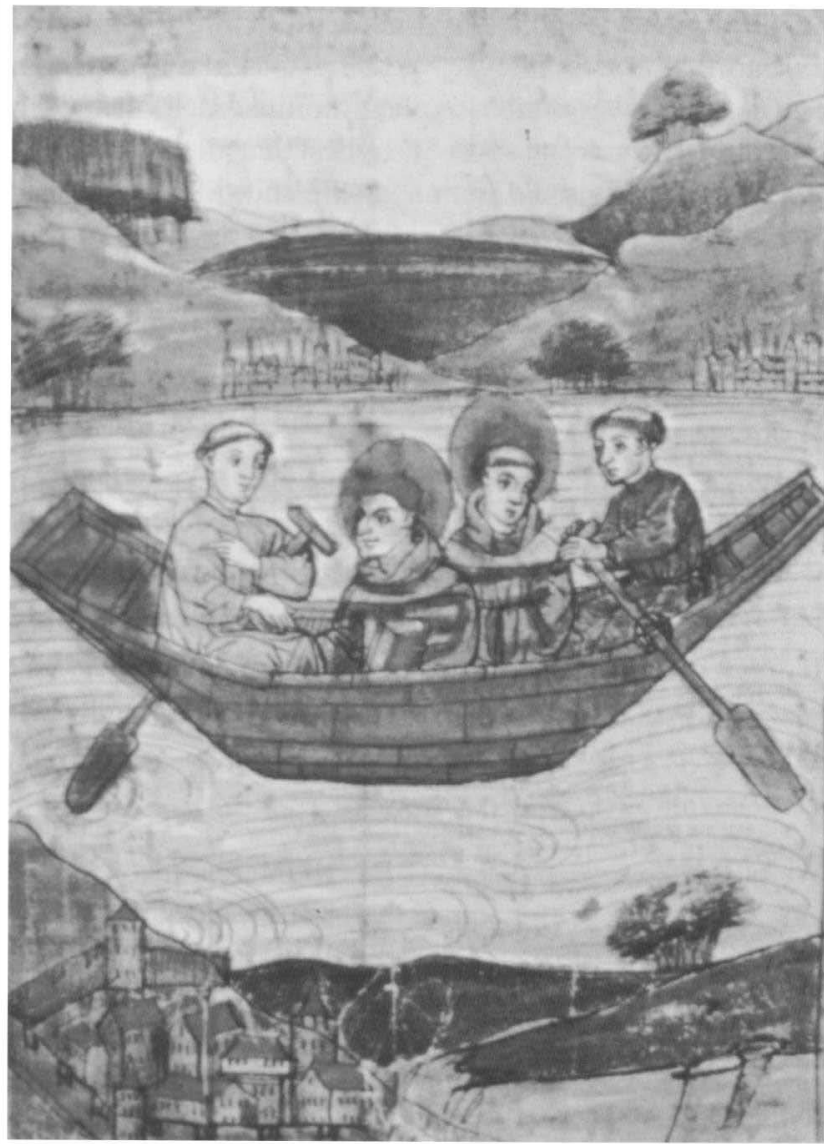

Fig. 30.3. St Gall and St Columban crossing Lake Constance in a flat-bottomed vessel. St Gallen, 1451-52 (courtesy of Stiftsbibliothek St Gallen, cod. 602, p. 33). rudder mounted in an oarlock near the bow was used for propulsion, the other aft for steering.

Flat-bottomed hull construction must have undergone a fundamental change in the 17th century. A shipwreck found near Unteruhldingen has been roughly surveyed, but still awaits further examination. The wreck is of a sailing vessel, $c a .30 \mathrm{~m}$ long, which was built using the bottom-based construction, but with carwel side-planking angling outward, the planks being pinned together by vertically driven iron nails some $40 \mathrm{~cm}$ in length. The hull, made of oak planks, no longer has a monoxyle chinestrake, but rather a composite chine made up of single planks. The frames are again curved branches hewn in shape and fixed by heavy iron bolts. Almost the same construction technique was employed for the last wooden sailing vessels of the early 20th century (Fig. 30.4, above; Bloesch, 1988). The sheer and body plans of a postmedieval Segner and the 14th-century Immenstaad vessel show clearly two different hull designs (Fig. 30.4):

- In the 12th to 15th centuries flat-bottomed hulls were built in the bottom-based construction and show a box-like body section with almost vertical sides. The bottom was edged by monoxyle chine-strakes carved from logs. The vertical side-planking was clinker built. Frames were made of logs with branches or roots angling away. Joints were fastened throughout by treenails, wedged from in- and outboard (Fig. 30.4, below).

- In the 17th century, shipwrights on Lake Constance developed another flat-bottomed bulbous hull design,

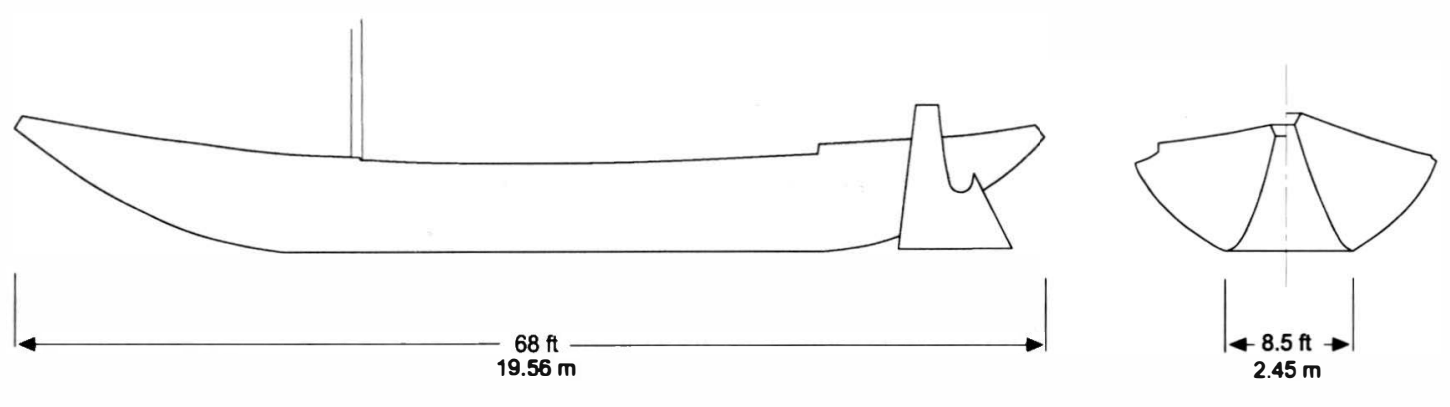

Segner, Lindau 18th-19th c. (1 Lindauer Werkschuh [Lindau foot] $=28.8 \mathrm{~cm}$ )

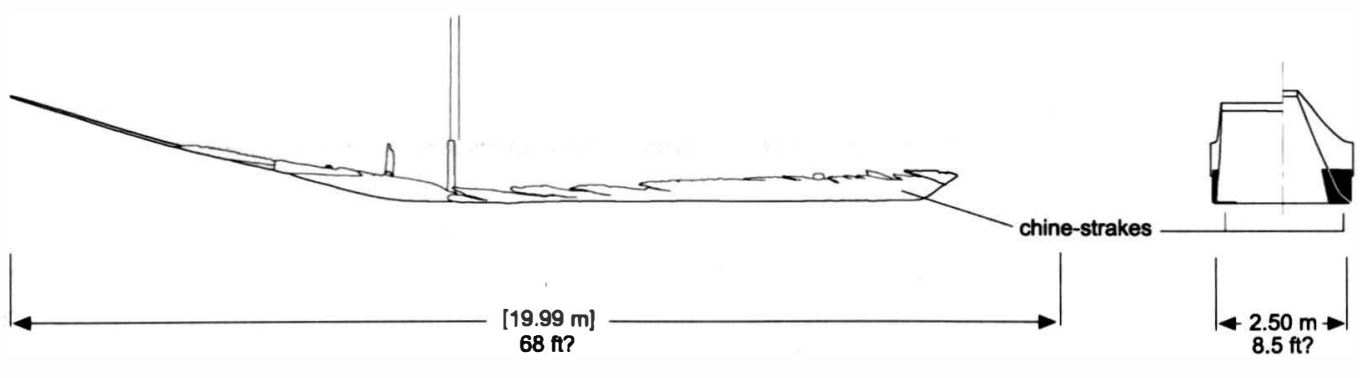

Immenstaad-Kippenhom, 14th c. $(1 \mathrm{ft}=29.4 \mathrm{~cm}$ ?)

Fig. 30.4. Sheer views of a post-medieval Segner and the medieval Immenstaad vessel. 
which was associated with a fundamental change of the bottom-based construction. The body section shows a considerable curvature of the sides. Side planking was now carvel built and angled outward, the strakes were flush and pinned together by long iron nails driven through the plank into the one beneath. Frames were still made of logs with branches or roots angling away, but were fixed by heavy iron bolts and nails. This hull design seems to have been retained almost unchanged until ca. 1900 (Fig. 30.4, above).

According to 18th-century records from the town of Lindau, the fundamental measurements of the Segner which had to carry a minimum load of over 44 tons were a length of 68 feet and an maximum internal bottom width of 8.5 feet (Hartmann, 1808: 82; Leidenfrost 1975: 69). With the Lindau foot (1 Werkschuh) of $28.8 \mathrm{~cm}$ as the unit, the total length of the Segner would be $19.56 \mathrm{~m}$.

The maximum internal bottom width of the 14thcentury Immenstaad vessel was $2.50 \mathrm{~m}$. According to the internal bottom width of 8.5 feet in the 18th and 19th centuries, a unit of $29.4 \mathrm{~cm}$ can be calculated, which could correspond to a medieval unit of 1 foot. With one foot of $29.4 \mathrm{~cm}$ and the traditional Segner-length of 68 feet, the original overall length of the $18 \mathrm{~m}$-long Immenstaad shipwreck could be calculated to have been about $20 \mathrm{~m}$ (Fig. 30.4, below).

The flat bottoms of both hulls, although separated in time by 500 years, not only had the same length, but also almost the same concurrent ratio of length/internal bottom width of $1: 8$. But the completely different hull design and wood technology resulted in very different capacities. The Lindau Segner could carry more than 44 tons, twice the cargo of the Immenstaad vessel, for which a maximum load of between 17 and 21 tons could be determined, depending on freeboard. It is possible that in the course of hull development a fundamental ratio of 1:8 was retained. However, hull design and construction had undergone a thorough change, as I have mentioned above. It therefore might be justifiable to interpret the Immenstaad wreck as the remains of a distinctive vessel type preceding the postmedieval Segner. On the other hand, pictorial sources suggest that vessels of the box-like "medieval" hull design were still built on Lake Constance in the 18th century, even until the 20th century elsewhere and sometimes employing chine-strakes (Beaudouin, 1985: 60-63, 119126).

The steering device promises to be another indicator for technological change in wooden shipbuilding on Lake Constance. Whereas in 15th- and 16th-century pictorial sources, two long rudders mounted in oarlocks to the fore and aft sides of the hull are clearly shown (Fig. 30.3), in the 16th century a remarkable side rudder came into use. which ultimately seems to have predominated on the lake in the 17th century, at least for the larger sailing vessels. This elegantly curved rudder-blade, called the "Schiffs- thür" (ship's door), pivoted on an iron pintle put through two gudgeons on the rudder blade itself and two others in the rudder beam, which crossed the hull aft (Fig. 30.1). So, apart from the change in hull construction and design, we also have a subsequent change of the steering device. Why were the long rudders abandoned in favour of a side rudder? The aforementioned changes in hull design and the increase in hull capacity undoubtely created the need for a steering device that enhanced the directional stability of the square-rigged flat-bottomed vessels. There is no reason to assume that the invention of the side rudder appeared from nowhere, but as far as I know, there is no comparable side rudder known on European inland waters. It could be possible, that a Dutch stern rudder design was adapted on Lake Constance and modified as a side rudder. Due to the gradually sloping flat-bottomed stern of the traditional hull on Lake Constance and the consequent lack of any vertical sternpost or transom stern, the bottombuilt concept could have forced the shipwrights to seek alternative solutions for mounting the rudder. The characteristic design and construction of the side rudder remained virtually unchanged until the early 20 th century (Fig. 30.1). Foreign influence does not seem to have generally affected shipbuilding on Lake Constance. 15th and 16th-century experiments with a galley "wie man sie auf dem Meere hat" (like one has on the ocean), for example, were exceptional and did not prove very successful (Hartmann, 1808: 83).

Whereas the technical development of the Roman and early medieval vessels on Lake Constance is still obscure, recent archaeological finds have been able to provide insight into medieval and post-medieval wooden shipbuilding. The archaeological and iconographical source situation allows us to trace long-term constructional changes between the 14th and the 17th centuries: from flat-bottomed hulls with vertical clinker side-planking and wooden fastenings throughout to flat-bottomed hulls with carvel-built, curved sides employing iron fastenings. Prospering medieval iron technology and the resultant availability of ironwork do not seem to have played a role in medieval shipbuilding on Lake Constance until the 16th century. The post-medieval abandonment of monoxyle chine-strakes and wooden treenails in favor of iron bolts and nails has to be seen in the context of advancing hull design. Additionally, in the 16th century the unique siderudder appeared. Both medieval and post-medieval hulls still had the flat bottom and the sloping extremities in common. The fundamental changes in flat-bottomed hull design and construction suggest an adaptation to new economic demands and the invention of new shipbuilding technologies. A prospering local economy and the developing global trade in the late Middle Ages possibly triggered them. The bottom-based construction seems to have been employed virtualiy unchanged until the decline of wooden shipbuilding on Lake Constance. The Segner was to survive until $c a$. 1910 when it was finally superseded by the railway lines encircling the lake. 


\section{Acknowledgements}

Thanks are due to Howard Weiner for correcting my English prose and for contributing to earlier drafts.

\section{References}

Arnold, B., 1976 La nâcon du Cudrefin (La Sapine), barque du XIXe siècle (lac de Neuchâtel, Suisse) et quelques remarques concernant les bateaux celtes. Cahiers d'archéologie subaquatique, 5: 105-120.

Arnold, B., 1985. From logboat to plankboat - Some traditional craft of Switzerland. In C.O. Cederlund (Ed.), Postmedieval Boat and Ship Archaeology: Papers based on those presented to an International Symposium on Boat and Ship archaeology in Stockholm in 1982. B.A.R. Int. Series 256, 285-297. Oxford.

Arnold, B., 1992, Batellerie gallo-romaine sur le lac de Neuchâtel. Tome 2 (Archéologie Neuchâteloise, 13). Saint-Blaise.

Beaudouin, F., 1985, Bateaux des fleuves de France. Douarnenez. Bloesch, P., 1988, Some Remarks on the Sailing Barges of Lake Constance. The Mariner's Mirror, 74: 321-327.

Bloesch, P., 1994, Inventing the Barque du Léman, Lake of Geneva, Switzerland/France. In C. Westerdahl (Ed.), Crossroads in Ancient Shiphuilding. Proceedings of the Sixth International Symposium on Boat and Ship Archaeology, Roskilde 1991. 229233. Oxford.

Eitel, P., Die historische Verkehrsfunktion des Bodenseeraumes. In E. Riedenauer (Ed.), Die Erschließung des Alpenraums für den Verkehr im Mittelalter und in der frïhen Neuzeit, 85-99. Bozen.

Hakelberg. D., 1996, A 14th-century vessel from Immenstaad (Lake Constance, southern Germany). The International Journal of Nautical Archaeology: 25.3-4: 224-233.

Hakelberg, D., Tegel, W., 1997, Neuentdeckte Fragmente eines hochmittelalterlichen Schiffes aus Überlingen, Bodenseekreis. Archäologische Ausgrabungen in Baden-Württemberg 1996: 260-264.

Hartmann, G. L., 1808, Versuch einer Beschreibung des Bodensee's. Zwote, sehr vermehrte und verhesserte Auflage. St. Gallen.

Leidenfrost. J.. 1975, Die Lastsegelschiffe des Bodensees. Sigmaringen.

Rieth, E., 1981, La construction navale au fond plat en Europe de l'Ouest. Ethnologie Française, 11: 47-62.

Schwab, G., 1840, Der Bodensee nebst dem Rheinthale von St. Luziensteig bis Rheinegg. Zweite Abtheilung (2nd ed.). Stuttgart.

Siefken, H., 1978, Verkehrsentwicklung und Provinzialisierung. Die Verkehrspolitik der bürgerlichen Fraktionen in Konstanz. In G. Zang (Ed.), Provinzialisierung einer Region. Regionale Unterentwicklung und liberale Politik in der Stadt und im Kreis Konstanz im 19. Jahrhundert. Untersuchungen zur Entstehung der hiirgerlichen Gesellschaft in der Provinz. 135-181. Frankfurt a. M.

Von Stromer, W.. 1986, Gewerbereviere und Protoindustrien in Spätmittelalter und Frühneuzeit. In H. Pohl (Ed.), Geverbe und Industrielandschaften vom Spätmittelalter his in das 20. Jahrhundert. Vierteljahresschrift für Wirtschafts- und Sozialgeschichte (Beiheft 78), 39-111. Wiesbaden. 